\title{
HUBUNGAN MUSLIM DAN NON-MUSLIM DALAM KERANGKA INKLUSIVISME
}

\author{
Rulyjanto Podungge \\ Institut Agama Islam Negeri Sultan Amai Gorontalo, Indonesia \\ E-mail: ruly.podungge@gmail.com
}

\begin{abstract}
When a society grows and the needs of its members increase, the relation between them and other people-who possess various primordial identities - will be impossibly avoided. This social relation will potentially bring about friction among different groups existed in the society. Islam has established a number of rules concerning the relationship of Muslims and other religious adherents. Although the regulations have been firmly settled, the controversy among the Muslims themselves-in dealing with their relation with the non-Muslims - is often inevitable. The issue of relation with other people of different religions has become contentiously debatable topic among the Muslim academics. The debate has subsequently brought about the emergence of different ideological inclinations within the Muslim society. This ideological preference emerges through such number of "appearances" as moderates, radicals, liberals, traditionalists, and modernists. Each group possesses its own perception along with its arguments about the issue. This article seeks to explain the pattern of Muslims and nonMuslims relation in the light of more moderate and contextual approach. This is so why that Muslims should constantly prioritize inclusive behavior and reciprocally sincere interreligious dialogue with their non-Muslim fellows.
\end{abstract}

Keywords: Muslim and non-Muslim relation; religious inclusivism and exclusivism; interreligious dialogue.

\section{Pendahuluan}

Pluralitas merupakan realitas dunia, baik dalam skala lokal maupun global. Pluralitas juga merupakan ciri utama Indonesia. Di samping keberagaman dalam agama, Indonesia dikenal sebagai negara di mana sejumlah agama besar bertemu dan berkembang secara harmonis. Dalam beberapa dekade, keberagamaan di Indonesia menjadi model kehidupan bagi suatu hubungan yang harmonis di 
mana orang dari latar belakang yang berbeda dapat hidup dan bekerja sama secara damai. Umat Islam, sebagai mayoritas penduduk Indonesia, dikenal sebagai golongan yang toleran dan sangat menjunjung tinggi nilai perdamaian. Akan tetapi, pada beberapa dekade terakhir, dunia internasional menyoroti dan memberikan peringatan akan adanya sikap yang intoleran yang mulai marak terjadi di Indonesia. Hal ini, terutama, setelah jatuhnya rezim Orde Baru di bawah kepemimpinan Presiden Suharto di saat ketika ruang kebebasan berpendapat dan berserikat mulai terbuka di negeri ini. Beragam kelompok dengan ideologi yang berbeda muncul ke permukaan dan menimbulkan ketegangan yang, pada satu sisi, menjadikan kehidupan sosial dinamis namun juga mendorong pecahnya konflik kekerasan yang berujung tragis di sisi lain.

Kemunculan sekelompok Muslim radikal barangkali menjadi salah satu citra negatif yang paling menonjol disandang Indonesia sejak saat itu hingga hari ini. Kelompok radikal ini tidak hanya menginginkan kepastian segala hal, akan tetapi juga secara aktif mencari kekuatan untuk memaksa orang lain mengikuti pendirian mereka, bahkan kadang dengan kekerasan. Ironisnya, mereka mengklaim berbicara atas nama Islam tetapi yang mereka lakukan sangat bertentangan dengan doktrin-doktrin Islam. Agama, pada titik ini, menjadi apa yang oleh Charles Kimbal disebut sebagai kekuatan pembunuh (a lethal force).$^{1}$ Dengan kata lain, pemeluk agama tidak saja tidak mengetahui ajaran agama lain, tetapi mereka juga tidak memahami dengan baik doktrin agama yang dipeluknya. Jika ini terjadi maka muncul kekhawatiran kita bersama bahwa mayoritas orang Indonesia adalah beragama, tetapi mereka juga yang paling tidak memahami ajaran agama.

Hal ini seakan memperlihatkan bahwa agama memiliki "wajah ganda" di mana di satu sisi ia memiliki wajah yang damai, ramah, penuh harmoni dan menyapa umat beragama lain dengan kasih sayang, namun pada sisi lainnya, agama tampil dengan sikap yang tidak ramah, intoleran, mengancam dan penuh klaim-klaim kebenaran sepihak. Dalam kehidupan keseharian, kondisi yang disebut terakhir mewujud dalam berbagai kekerasan sosial yang berbasis agama.

David Lockhead menjelaskan bahwa di dalam setiap tradisi keagamaan selalu terkandung benih-benih ideologi dan atau teologi yang bersifat isolasionis, di mana masing-masing umat beragama hidup

${ }^{1}$ Charles Kimbal, When Religion Becomes Lethal (San Fransisco: Jossey Bass 2011), 43. 
dan berkembang dalam ghetto-nya masing-masing, konfrontasionis, dan bahkan membenci yang lain. Batas-batas ketiganya sangatlah tipis dan kabur, apalagi ketika hal ini dikaitkan dengan logika kekuasaan yang ada dalam setiap institusi keagamaan berupa pengakuan absolut yang menjadi bahasa dominan agama. ${ }^{2}$ Dengan kata lain, jika kondisi ini dibiarkan, yang terjadi adalah pereduksian nilai-nilai agama di mana agama berubah dari instrumen yang membawa pesan-pesan kasih sayang dan kebersamaan menjadi instrumen yang menciptakan kekerasan dan tindakan intoleransi, maka kemudian yang berkembang adalah perasaan saling curiga dan saling melihat pihak lain sebagai musuh.

Kekerasan bernuansa agama selama berabad-abad merupakan kejahatan terburuk yang telah mengisi peradaban manusia. Hal ini tentu menjadi sesuatu yang paradoks karena agama mengajarkan nilainilai luhur, tetapi ia juga yang bertanggung jawab terhadap terjadinya kerusakan di muka bumi ini. Mengapa agama yang mengajarkan kesejukan, kedamaian, kasih sayang dan nilai-nilai ideal lainnya, kemudian tampil dengan wajah yang keras, garang dan menakutkan?

Agama kerap dihubungkan dengan radikalisme, ekstrimisme, bahkan terorisme. Agama dikaitkan dengan bom bunuh diri, pembantaian, penghancuran gedung, dan lain-lain yang menunjukkan penampilan agama yang menakutkan. Tidak dapat dipungkiri, bahwa manusia yang menghuni muka bumi ini begitu heterogen terdiri dari berbagai suku, etnis, ras, penganut agama, kultur, peradaban dan sebagainya. Pada titik inilah peran agama sebagai perekat heterogenitas dan pereda konflik sudah lama dipertanyakan.

Samuel P. Huntington mengatakan bahwa perbedaan tidak mesti konflik dan konflik tidak mesti berarti kekerasan. Dalam dunia baru, konflik-konflik yang paling mudah menyebar dan sangat penting sekaligus paling berbahaya bukanlah konflik antarkelas sosial, antargolongan kaya dengan golongan miskin, atau antara kelompokkelompok (kekuatan) ekonomi lainnya, tetapi konflik antara orangorang yang memiliki entitas-entitas budaya yang berbeda-beda. ${ }^{3}$

Dalam konteks kekinian, bentuk-bentuk konflik, kekerasan dan perang agama akan memperoleh tempat yang semakin nyaman

\footnotetext{
2 David Lockhead, "The Dialogical Imperative", dalam Anas Aijuddin, Pluralisme dan Tantangan Dialog antar Agama (Jakarta: Gramedia Pustaka Utama, 2014), 321.

${ }^{3}$ Fita Vitria, "Konflik Peradaban Samuel P. Huntington: Kebangkitan Islam yang Dirisaukan”, Humanika, Vol. 9, No. 1 (2009), 39-52.
} 
andaikata masing-masing kontestan kekerasan berangkat dari argumentasi agama. Sehingga, selama berabad-abad, perbedaan entitas agama telah menimbulkan konflik yang paling keras dan paling lama, paling luas, dan paling banyak memakan korban. Dalam citranya yang negatif, agama telah memberikan kontribusi terhadap terjadinya konflik, penindasan dan kekerasan. Agama telah menjadi tirani di mana atas nama Tuhan orang melakukan kekerasan, menindas, melakukan ketidakadilan dan pembunuhan.

Kondisi ini merupakan tanda bahwa agama telah berubah, bergerak menjadi instrumen yang destruktif. Di sisi lainnya kondisi ini sebenarnya juga menjadi tantangan semua agama untuk terus mendorong umatnya memahami agama tidak hanya sebatas pada doktrin dogmatik, melainkan juga ranah yang lebih tinggi, lebih historis. Dalam konteks agama Islam, menurut Amin Abdullah, perlu adanya pemahaman Islan secara mendalam agar umat Islam mampu memberi sumbangan dalam kehidupan. Hal ini bisa dilakukan hanya jika umat Islam memahami setiap ajaran agamanya tidak hanya secara doktriner-monolitik, tetapi juga yang bersifat pluralistik-historis. ${ }^{4}$

\section{Islam dan Relasi Antarmanusia}

Hubungan antarmanusia dalam konteks Islam lazim dikenal dengan istilah mu'ämalah bayn al-nās. Berbeda dari ibadah yang merupakan dimensi hubungan manusia dengan Allah dan muamalah mengatur bagaimana hubungan manusia dengan sesamanya. Bidangbidang yang diatur oleh muamalah mencakup hubungan ekonomi dan kehidupan sehari-hari umat Islam. Dengan kata lain, muamalah berbicara tentang aspek privat, yakni hubungan individu dengan individu serta hubungan individu dengan kelompok. Dalam konteks relasi inilah perbedaan yang menyangkut identitas sosial, primordialisme dan ideologi, termasuk di dalamnya identitas agama, tidak bisa dipungkiri dan dihindari.

Berkaitan dengan hubungan dengan penganut agama lain, Islam telah menggariskan bagi pemeluknya rambu-rambu dan batasanbatasan yang boleh dilakukan dan yang tidak. Meski demikian, tetap saja kontroversi dalam ranah ini seringkali tidak bisa dihindarkan. Oleh karena itu, penting untuk sejak awal digarisbawahi bahwa isu

\footnotetext{
${ }^{4}$ M. Amin Abdullah, "Studi Islam Ditinjau dari Sudut Pandang Filsafat: Pendekatan Filsafat Keilmuan", dalam Amin Abdullah, dkk., Restrukturisasi Metodologi Islamic Studies Madhab Yogyakarta (Yogyakarta: SUKA Press, 2007), 6.
} 
relasi dengan non-Muslim termasuk salah satu isu yang cukup sensitif dalam Islam.

Di dalam al-Qur'ān terdapat banyak ayat yang membolehkan Muslim untuk berhubungan dengan kelompok di luar agama Islam, ayat-ayat itu diantaranya: pertama, ayat 60 surah al-Mumtahanah: Allah tidak melarang kamu untuk berbuat baik dan berlaku adil terbadap orangorang yang tiada memerangimu karena agama dan tidak (pula) mengusir kamu dari negerimu. Sesunggubnya Allah menyukai orang-orang yang berlaku adil." Kedua, ayat 40 surah al-Hajj: "(yaitu) orang-orang yang telab diusir dari kampung halaman mereka tanpa alasan yang benar, kecuali karena mereka berkata: "Tuhan kami hanyalah Allab". Dan sekiranya Allab tiada menolak (keganasan) sebagian manusia dengan sebagian yang lain, tentulah telah dirobobkan biara-biara Nasrani, gereja-gereja, rumah-rumah ibadat orang Yabudi dan masjid- masjid, yang di dalamnya banyak disebut nama Allah. Sesunggubnya Allah pasti menolong orang yang menolong (agama)-Nya. Sesunggubnya Allab benar-benar Maha Kuat lagi Maha Perkasa.

Ketiga, ayat 2 surah al-Māiidah: Hai orang-orang yang beriman, janganlah kamu melanggar syiar-syiar Allah, dan jangan melanggar kehormatan bulan-bulan haram, jangan (mengganggu) binatang-binatang "bady" dan binatang-binatang qaläid, dan jangan (pula) mengganggu orang-orang yang mengunjungi Baitullah sedang mereka mencari kumia dan keridaan dari Tubannya dan apabila kamu telah menyelesaikan ibadah baji maka boleblah berburu. Dan janganlah sekali-kali kebencian-(mu) kepada sesuatu kaum karena mereka menghalang-halangi kamu dari Masjidil Haram mendorongmu berbuat aniaya (kepada mereka). Dan tolong-menolonglah kamu dalam (mengerjakan) kebajikan dan takwa, dan jangan tolong-menolong dalam berbuat dosa dan pelanggaran, dan bertakwalah kamu kepada Allah. Sesunggubnya Allah amat berat siksa-Nya.

Di sisi lain, al-Qur'ān juga memberikan ketentuan bagi orang Islam untuk selektif dalam menjalin hubungan dengan non-Muslim. Hal ini, misalnya, ditemukan dalam ayat 89 surah al-Nisā': Mereka ingin supaya kamu menjadi kafir sebagaimana mereka telah menjadi kafir, lalu kamu menjadi sama (dengan mereka). Maka janganlah kamu jadikan di antara mereka penolong-penolongmu, hingga mereka berbijrah pada jalan Allah. Maka jika mereka berpaling, tawan dan bunublab mereka di mana saja kamu menemuinya, dan janganlah kamu ambil seorangpun di antara mereka menjadi pelindung dan jangan (pula) menjadi penolong.

Ayat yang disebutkan terakhir ini memiliki sabab al-nuzūl (konteks yang melatarbelakangi diturunkannya suatu ayat atau surah dalam al- 
Qur'ān). Terkait ayat ini diriwayatkan bahwa beberapa orang Arab datang kepada Rasulullah di Madinah lalu mereka masuk Islam. Sesaat setelah mereka memeluk Islam, mereka tertimpa sakit demam. Karena itulah mereka kemudian kembali menjadi kafir lalu keluar dari Madinah. Dalam perjalanannya mereka berjumpa dengan beberapa sahabat Nabi. Para sahabat menanyakan sebab-sebab mereka meninggalkan Madinah. Orang-orang tersebut menerangkan bahwa mereka ditimpa demam. Para sahabat kemudian berkata: "Mengapa kalian tidak mengambil teladan yang baik dari Rasulullah?" Menyikapi kasus ini, para sahabat terbagi kepada dua golongan di mana sebagian berpendapat bahwa orang-orang Arab Badui tersebut menjadi munafik, sementara sebagian lagi berpendapat bahwa mereka masih Islam. Kemudian, turunlah ayat tersebut yang mencela kaum Muslimin karena menjadi dua golongan itu. Ayat ini bahkan memerintahkan agar orang-orang Arab itu ditawan dan dibunuh jika mereka tidak berhijrah ke Madinah. Hal ini karena mereka disamakan dengan kaum musyrikin yang lain, sebagaimana disinyalir dalam alQur'ān surah al-Nisā' ayat 4 dan surah al-Mā'idah ayat $51 .{ }^{5}$

Hubungan antara Muslim dan non-Muslim tidak hanya berkaitan dengan hal-hal yang bersifat sosial dan kasat mata, tetapi juga tak kalah pentingnya adalah bagaimana membangun mental persaudaraan yang kokoh di antara berbagai keyakinan teologis yang berbeda itu. Dengan demikian, di luar perbedaan teologis yang merupakan keniscayaan itu, ada nilai-nilai universal yang mampu menyatukan mereka. ${ }^{6}$

\section{Menjawab Globalisasi}

Sejarah manusia selalu bergerak dinamis. Dari zaman di manam manusia tidak mengenal baca tulis bergerak ke dalam struktur teknologi yang luar biasa. Ada banyak implikasi dari perubahanperubahan media dan teknologi tersebut baik sosiologis, antropologis, kultural, bahkan teologis. Masing-masing bergerak menuju peradaban baru. Jika pada masa lalu teknologi tradisional telah menyekat manusia dalam batas-batas geografis, sehingga salah satu kriteria untuk mengidentifikasi perbedaan manusia adalah letak wilayah di mana

\footnotetext{
${ }^{5}$ Jalāl al-Dīn Muḥammad al-Maḥallī, Jalā' al-'Aynayn 'alà Tafsìr al-Jalālayn (Kairo: Dār al-Salām, 1993), 92.

6 Pradana Boy, Fikih Jalan Tengah: Dialetika Hukum Islam dan Masalah-masalah Masyarakat Modern (Jakarta: Penerbit Hamdalah, 2008), 215.
} 
suatu komunitas tinggal, maka hari ini batas-batas fisik semacam itu tidak lagi memainkan peran dan fungsi yang signifikan, meskipun untuk tingkat dan kasus tertentu kenyataan itu masih berlaku. Akibatnya, pola hubungan manusia yang dulu bersifat sangat konvensional kini telah digantikan dengan pola hubungan yang serba mekanistis yang dengan sendirinya merelatifkan jarak geografis yang secara fisik sangat tidak terjangkau.

Belakangan ini, salah satu tantangan terbesar masyarakat dunia adalah merespons sebuah gelombang yang disebut sebagai globalisme. Istilah "global" telah menjadi satu hal yang fenomenal dan sekaligus menantang. Fenomenal, karena istilah ini merujuk kepada suatu kondisi yang menuntut suatu "unifikasi" universal dalam semua bidang kehidupan. Menantang, karena justru dengan tuntutan unifikasi itulah, manusia dituntut untuk bisa memaknai setiap perbedaan, apapun perbedaan itu, dalam konteks yang lebih esensial dan bukan sekedar fenomenal. Ini karena yang fenomenal tidak serta merta mencerminkan esensial.

Dengan kerangka ini, menjadi mudah dipahami mengapa akhirakhir ini lahir sebuah tuntutan untuk membentuk sebuah unifikasi teologi agama-agama dunia dalam satu konteks universalitas yang dikenal sebagai "teologi global". Mempertimbangkan persoalan kemanusiaan pada level global, maka sebuah pemaknaan akan relasi antaragama dalam bingkai "teologi global" menjadi sangat urgen. Akan lebih menguntungkan, jika teologi dipahami sebagai bingkaibingkai transendental dalam kehidupan manusia. Asumsi inilah yang melahirkan banyak istilah teologi yang dirujuk kepada berbagai sistem kehidupan, misalnya teologi politik, teologi pembebasan dan lain-lain. Secara implisit hal itu menunjukkan bahwa teologi memang menjadi bingkai transendental dari seluruh praktik kehidupan.

Teologi politik, misalnya, menyatakan bahwa praktik politik tidak dapat dipisahkan begitu saja dari nilai-nilai transendental, betapapun menganggap nilai politik dan nilai agama sebagai satu hal yang sama merupakan hal yang sangat tidak mendasar. Demikian juga dengan teologi pembebasan yang menyatakan bahwa teologi bisa tampil sebagai spirit perjuangan untuk memerangi berbagai ketimpangan yang terjadi dalam kehidupan manusia pada level sosial. ${ }^{7}$

Di sinilah, tantangan yang harus dihadapi teologi semakin kompleks. Berkaitan dengan globalisme, maka tantangan yang harus

${ }^{7}$ Ibid. 
dipecahkan oleh teologi, diantaranya, adalah bagaimana mengkonstruksi sebuah paragdima teologi baru yang mampu mendudukkan nilai-nilai kemanusiaan dalam satu terma universal. Lahirnya teologi global, bisa dianggap sebagai salah satu upaya untuk merespons tuntutan itu.

Dalam level yang jelas, secara sederhana istilah global dapat berarti "seluruh dunia", yang jika diterapkan pada istilah teologi, maka itu akan mengasumsikan bahwa teologi harus mencakup semua agama dan bukan agama dari wilayah-wilayah tertentu. Pada level yang lain, ide global dalam teologi mengimplikasikan adanya kebutuhan untuk mengambil secara serius pandangan dan kajian ilmiah dari bagian dunia yang lain, sehingga teologi bisa menjadi bersifat global dan tidak hanya bersifat Kristen atau Barat. Teologi global adalah teologi agama yang menegaskan bahwa tradisi agama yang berbeda diarahkan pada satu anggapan bahwa semua agama (kebudayaan dan bangsa) berada pada satu continuum etika yang sama. Oleh karena itu dibutuhkan kerja sama antara berbagai model teologi untuk menciptakan sebuah dunia yang harmonis dan berkesinambungan.

Teologi global juga berhubungan dengan devolusi pola dan sikap keberagamaan masyarakat dunia. John Hick, misalnya, membagi pemikiran dan sikap agama-agama dunia ke dalam tiga tipe: pertama, eksklusivisme, yaitu pemikiran yang memosisikan agama lain mutlak salah dan agama sendiri mutlak benar. Kedua, inklusivisme di mana posisi agama lain diakui mengandung kebenaran religius tetapi pada akhirnya semua posisi agama itu included dalam posisi satu agama. Ketiga, pluralisme, yaitu pemikiran bahwa tradisi agama memuat konsepsi yang berbeda dan respons yang berbeda pula pada yang nyata, dari uraian utama ciri kultural menjadi manusia. ${ }^{8}$

Secara teologis, lahirnya agama-agama besar dunia selalu diiringi dengan proses pewahyuan yang melibatkan proses-proses kemanusiaan dan, terlebih, proses transendental. Artinya, wahyu yang diyakini sebagai suatu realitas sakral dalam setiap tradisi agama itu harus diterjemahkan dalam konteks yang lebih "membumi". Dalam konteks inilah dalam studi agama lazim dikenal istilah hermeneutika yang menunjuk pada understanding of understanding. Bahwa suatu ayat

8 Lihat Ahmad Khoirul Fata, "Liberalisme Islam di Indonesia: Gagasan dan Tanggapan tentang Pluralisme Agama," (Tesis--IAIN Sunan Ampel Surabaya, 2006). Lihat juga, Ahmad Khoirul Fata dan Fauzan, "Kritik 'INSIST' terhadap Gagasan Pluralisme Agama”, Kalam, Vol. 11, No. 1 (2017), 31-56. 
atau teks kitab yang diturunkan dalam formulasi-formulasi bahasa tertentu sebenarnya mengandung makna yang jauh melampaui struktur bahasa yang digunakan itu. Sebab spekulasi menyatakan bahwa istilah hermeneutika sebenarnya diambil dari nama dewa Hermes dalam mitologi Yunani. Hermes adalah dewa yang tugas utamanya adalah memintal. Secara sederhana, Hermes dianggap sebagai "pemintal" wahyu Tuhan yang turun dengan bahasa langit untuk dipersembahkan kepada manusia dengan menggunakan bahasa bumi, sehingga manusia mampu memahaminya. ${ }^{9}$

Karena wahyu turun dalam kondisi masa, ruang, dan konteks yang sangat spesifik, maka merupakan satu hal yang tergolong wajar jika, dalam beberapa hal, satu agama cenderung berbeda dari agama yang lain. Betapapun, kaum pluralis menganggap bahwa perbedaan antara agama-agama dunia itu hanya ada pada level eksoterik, sementara pada level esoterik semua agama pada dasarnya merupakan ekspresi untuk mencapai kebenaran yang sama. Ibarat roda, pusat roda itu adalah Tuhan, dan jari-jari itu adalah jalan dari berbagai agama. Persoalan yang seringkali muncul adalah perbedaan struktur teologi satu agama dengan agama yang lain. Frank Whaling, sebagaimana dikutip oleh Pradana Boy, menyebutkan bahwa dalam tiap-tiap agama terdapat delapan elemen yang secara etis melekat padanya. Kedelapan elemen itu adalah komunitas religius, ritual, etika, keterlibatan politik dan sosial, kitab suci, konsep atau doktrin, estetika, dan spiritualitas. Meski Whaling menganggap kedelapan hal ini mutlak ada dalam setiap tradisi agama, tetapi bisa saja satu agama dengan agama yang lain memuat bobot yang tidak sama pada masing-masing elemen tersebut.

Tidak hanya dalam bobot yang diberikan kepada elemen-elemen itu yang berbeda, tetapi juga dalam bentuk yang diambil. Dalam aspek doktrin, misalnya, tiap-tiap agama monoteis menekankan pentingnya Tuhan. Pada level yang lebih jauh, perbedaan dalam doktrin itu juga menyangkut keyakinan bahwa agama yang datang belakangan, khususnya dalam tradisi monoteis, berfungsi "membatalkan" agamaagama yang datang sebelumnya. Yang paling dirugikan dengan doktirin ini tentu Yahudi, karena sebagai agama monoteis tertua, justru Yahudilah yang menjadi sasaran pertama kali dari "pergeseran" oleh agama-agama yang serumpun dengannya.

${ }^{9}$ Karlina Helminita, Agama dan Hak Asasi Manusia: Landasan Filosofis Konsep Hak Asasi Manusia (Jakarta: CSRC UIN Syarif Hidayatullah, 2009), 19. 
Demikian pula dengan Islam, bahwa ia datang untuk membatalkan agama Nasrani. Beragam alasan bisa diturunkan untuk menolak atau menerima doktrin ini. Penolakan atas doktrin ini didasarkan pada keyakinan di antara agama-agama terdahulu bahwa bagaimana mungkin sebuah agama baru akan menggeser dan memperbaharui agama lama, sementara secara teologis agama itu telah mapan. Lagi pula, bukankah agama Nasrani, dalam kasus "pembatalan" terhadap Yahudi, dalam Islam dalam kasus pembatalan terhadap Nasrani, diturunkan dalam rentang waktu yang cukup panjang dari agama sebelumnya, yang berarti kitab suci masing-masing agama itu telah terkodifikasi secara demkian sempurna. Bagaimana mungkin, sebuah tradisi agama yang baru lahir akan memperbaharui agama yang telah memiliki kitab suci secara sempurna? Dan, bukankah ketika suatu agama baru lahir, berarti pewahyuan dan tradisi lama telah berakhir, yang berarti ajaran suatu tradisi agama itu telah paripurna? ${ }^{10}$

Dalam konteks Indonesia, penolakan terhadap tiga model beragama yang dikemukakan John Hick itu juga marak dilakukan oleh sebagian sarjana dan tokoh agama. Menurut mereka, konsep tersebut sangat bernuansa kristiani karena disimpulkan oleh Hick setelah mengamati perkembangan teologi Gereja yang berkembang dari teologi yang bersifat tertutup, kemudian beranjak ke sikap yang lebih terbuka, dan akhirnya menjadi sikap yang pluralis. Meski demikian, sebagian sarjana dan teolog menolak penerapan konsep tersebut ke dalam konteks Islam. Alasan utama penolakan tersebut adalah terdapat kandungan relativisme kebenaran dan paralelisme agamaagama dalam teologi pluralisme agama. ${ }^{11}$ Islam, menurut Ahmad Khoirul Fata, sesungguhnya merupakan agama yang bersifat eksklusif. Meski demikian dalam Islam terkandung elemen-elemen ajaran yang menutup pintu-pintu agresivitas kepada umat agama lain yang berbeda, dan di saat bersamaan mendorong pemeluknya untuk bersikap toleran kepada mereka. Dengan demikian Fata menyimpulkan bahwa sesungguhnya Islam merupakan agama eksklusif yang toleran. ${ }^{12}$

10 Ali Harb, Nalar Kritis Islam Kontemporer, terj. Umar Bukhory dan Ghazy Mubarak (Yogyakarta: IRCiSoD, 2012), 309.

11 Boy, Fikib Jalan Tengah.

12 Ahmad Khoirul Fata, "Menguak Islam Eksklusif yang Toleran", Islamica: Jurnal Studi Keislaman, Vol. 6, No. 1 (2011), 11-24. 
Pandangan yang lebih moderat tentang hal ini, mengatakan, ketiga agama monoteistik ini merupakan satu continuum yang saling berhubungan. Artinya, dalam teori fenomenologi agama, memahami Islam tidak akan dapat dilakukan dengan utuh tanpa memahami sejarah lahirnya agama Yahudi dan Nasrani. Benih-benih "kerja sama" antara ketiga agama ini sebenarnya telah ada. Dalam Islam, misalnya, terdapat sebuah doktrin bahwa keyakinan kepada kebenaran misi para nabi sebelum Muhammad merupakan salah satu syarat sahnya bagi keimanan Muslim. Tanpa meyakini kebenaran risalah yang dibawa oleh nabi-nabi terdahulu, sama halnya dengan mengingkari garis penghubung antara para nabi yang berakhir pada Nabi Muhammad. Continuum antara ketiga agama ini juga bisa dilihat pada peran yang dimainkan oleh ketiga agama besar ini dalam sejarah manusia dan kemudian lewat ketiganyalah manusia belajar memandang kemanusiaan sebagai suatu keseluruhan.

Di sisi lain, kita tidak bisa menghindari bahwa masing-masing pemeluk keyakinan memiliki sikap teologis yang berbeda. Berdasarkan pembagian yang dibuat Hick, Islam sebenarnya bukan agama eksklusif, dalam pengertian di atas. Pengakuan Islam terhadap kontinuitas kebenaran nabi-nabi terdahulu dari Nabi Muhammad sebagai salah satu dasar diterimanya kebenaran Islam, merupakan bukti yang teramat gamblang atas sifat dan sikap Islam yang justru inklusiv.

Pemeluk agama seharusnya menunjukkan tangung jawab moral dan sosial untuk memperjuangkan nilai-nilai keadilan, membangun kesetaraan, mengambangkan demokrasi, dan menghormati kehidupan sipil. Melalui nilai-nilai keadilan di dalam kehidupan sipil umat beragama diharapkan berempati terhadap agama-agama lain, dan mampu memahami bahwa agama adalah sebuah fenomena universal. Setiap agama memiliki muatan spiritualitas dan metafisis di mana kedua dimensi ini dapat dijadikan sebagai alat untuk menghubungkan dan mencari dasar-dasar persamaan antaragama.

Jika dikembangkan lebih lanjut, posisi metafisis dapat melampui fungsi teologi. Jika teologi selalu dimulai dengan asumsi/keyakinan absolut tentang kebenaran suatu agama tertentu dan agama lain mutlak salah yang menciptakan konflik antara umat beragama, maka aspek metafisis mampu menawarkan dialog melalui jalan afirmasi ulang dan meremajakan pemahaman tentang dan untuk apa teologi itu ada. Dalam hal ini, teologi memiliki beberapa keterbatasan untuk 
menyatukan ujung-ujung kebenaran masing-masing agama sehingga teologi membutuhkan dimensi metafisis sebagai alat pelegkapnya.

Dalam tulisan yang bertajuk When Mystic Master Meet: Towards a New Matrix for Christian-Muslim Dialoque, Syafaatun al Mirzanah, sebagaimana dikutip oleh Mibtadin, menyimpulkan bahwa menjadi agamis adalah dengan bersifat interreligious dalam pemahaman keagamaan, meskipun dalam pendekatan mistik tentulah akan berbeda dengan metafisik. ${ }^{13}$

Memahami agama dalam bingkai teologi global mampu menghadirkan kembali fungsi sosial agama yang selama ini hanya berkutat pada hal-hal yang besifat retorik, ideologis dan tidak mampu berbuat banyak pada kehidupan sesungguhnya. Maraknya kerusuhan yang terus terjadi, kekerasan dan radikalisme yang berkedok agama di beberapa tempat merupakan akibat dari adanya eksklusivisme agama. Agama telah menjadi sumber ketidakadilan dan ketidakharmonisan di antara sesama umat manusia di bumi. Pada kasus ini kita mengkhawatirkan fakta bahwa agama menjadi faktor pemisah antara sesama manusia.

Menurut M. Amin Abdullah, sesungguhya setiap agama membawa kedamaian bagi keseluruhan umat manusia dan harus diwujudnyatakan di dalam masyarakat yang plural, seperti negara kita Indonesia. Lebih lanjut Amin menunjukkan sikap yang sangat tidak setuju dengan berbagai gerakan fundamentalisme yang cenderung menggunakan kekerasan untuk mencapai tujuan, karena kekerasan atas nama agama adalah jalan dari pengingkaran dan pendangkalan terhadap agama itu sendiri; bukankah agama adalah jalan keselamatan? Kekerasan juga akan menghilangkan nilai-nilai universal yang dikandung dalam agama. Menurutnya, tidak ada alasan untuk mengembangkan sikap permusuhan kepada kelompok agama lain, karena masih selalu ada kemungkinan untuk berdialog. ${ }^{14}$

Menumbuhkan kesadaran untuk saling memahami masing-masing kultur kelompok manusia pada agama mereka dalam bingkai teologi diharapkan mampu meminimalkan kepentingan dalam meredakan konflik sosial keagamaan. Setiap kelompok agama perlu menekankan

\footnotetext{
${ }^{13}$ Syafa'atun al-Mirzanah, When Mystic Master Meet: Towards a New Matrix for ChristianMuslim Dialogue (New York: Blue Domes Press, 2011). Dikutip dari Mibtadin, Nalar Kritis dalam Beragama (Jakarta: Gramedia Pustaka, 2014), 343.

14 M. Amin Abdullah, "Relevansi Studi Agama-agama dalam Milenium Ketiga: Upaya Memecahkan Persoalan Keagamaan Kontemporer," Jurnal Ulumul al-Qur'ān, No. 5, Vol. VII, 56.
} 
sisi-sisi persetujuan dan kesepakatan dengan mengakui adanya perbedaan dan mencari titik temu dengan prinsip ajaran yang bersifat saling menguntungkan di antara umat. Titik tekan pada pemahaman dan pertemanan sebagai sesama penduduk bumi yang menghasilkan prinsip masing-masing dalam bingkai saling memahami dan saling berteman merupakan hal penting. Usaha-usaha ke arah tersebut akhirakhir ini ditempuh misalnya dengan teori meyandingkan kitab suci masing-masing agama secara sejajar dalam posisi menghadap ke arah yang sama, misalnya tema tentang kasih sayang Tuhan, cinta kepada sesama dan tema-tema universal lainnya yang menyatukan manusia.

Sikap saling menghargai tidak boleh berstandar ganda dan tidak pula boleh mengabaikan keadilan kepada siapapun, termasuk kepada orang yang berlainan agama. Agama diharapkan bisa menjadi media untuk membangun kehidupan yang saling memahami dan menciptakan perdamaian dan harmoni dalam perbedaan.

Usaha yang dilakukan oleh para pemuka Muslim di seluruh dunia melalui inisiatif dua prinsip kesamaan agama, yaitu kecintaan terhadap Tuhan sekaligus kasih sayang terhadap sesama manusia yang biasanya diistilahkan dengan istilah Common Word adalah sebuah gerakan kesalingpamahan antaragama. Dalam kerangka kesalingpahaman pandangan atas kepercayaan lain akan lebih positif jika diimbangi dengan semangat pencarian pemahaman. Ini akan memicu keingintahuan sejarah teologis khususnya antaragama yang dibawa oleh Nabi Ibrahim dan keturunannya. Penyelidikan teologi komparatif seperti itu diharapkan dapat menimbulkan gairah dialog yang toleran. Dialog mengenai kondisi kenabian, dan kondisi pemwahyuan, inkarnasi, dan keesaan Tuhan akan menjadi lebih terbuka dan toleran.

Menimbang isu ketuhanan berada pada wilayah di luar duniawi memunculkan kebingungan atas petunjuk kebenaran dogma teologis. Pada titik inilah metafisika berfungsi sebagai alat transenden dogma melalui ilustrasi bagaimana sebuah bentuk berasal dan apa tujuannya. Aspek metafisis dapat melengkapi teologi jika teologi tidak lagi mampu mempertemukan ragam perbedaan. Metafisis diharapakan mampu memperhalus pandangan berbeda antarkutub dalam sebuah ilustrasi ilmiah dari sisi kemanusiaan. Hal ini dapat menjadi modal untuk dialog agama yang lebih toleran.

Saat metafisika diapakai sebagai alat dialog antaragama yang toleran, harus ada kesepakatan bahwa polemik keagamaan harus diimbangi dengan semangat saling memahami. Karakter-karakter 
filsafat yang bersifat reflektif kritis berfungsi memberikan kejernihan pola pikir; dan ini adalah hal yang sangat penting. Karenanya, selain bisa dijelaskan secara rasional melalui filsafat, kajian keagamaan juga bisa dikritisi dalam dinamika dunia yang terus berkembang. Dalam konteks ini, pemaknaan terhadap agama akan baik jika dihubungkan dengan pengetahuan tentang kemanusiaan dan kemasyarakatan.

Di tempat lain kita melihat adanya gairah yang luar biasa besar untuk menjadikan agama-agama dunia sebagai sebuah benteng moral dan transendental atas berbagai persoalan kemanusiaan global pada abad ini. Satu hal yang perlu disadari bahwa sulit bagi agama untuk mencapai fungsi dan kedudukan tersebut, ketika masing-masing agama masih memegang secara kuat sikap eksklusivisme keberagamaan seperti yang dikategorikan Hick di atas. Praktis, dunia kini membutuhkan satu model teologi yang dikenal sebagai teologi global atau teologi universal. Sejumlah ilmuwan agama, seperti Ninian Smart, Hans Kung dan Frank Whaling begitu optimis dengan proyek ini, meskipun mereka menaruh keraguan kepada agama tertentu, bahkan Smart secara tegas meyatakan proyek ini akan gagal diberlakukan kepada sistem teologi Hinduisme dan Buddhisme.

Menyikapi isu teologi global ini, sebagai masa depan kehidupan antarumat beragama, Syafaatun al-Mirzanah mengungkapkan pentingnya dialog antaragama sebagai ruh dalam pengelolaan kehidupan dewasa ini. ${ }^{15}$ Ketertutupan, sifat eksklusivisme dan keengganan berdialog adalah pertanda bahwa umat beragama menuju pada jalan buntu dalam beragama, jalan yang tidak memberi masa depan bagi kemanusiaan.

Sejalan dengan pendapat al-Mirzanah tersebut, Leonard Swidler mengatakan bahwa dialog haruslah berorientasi untuk memperkaya pengalaman keberagamaan seseorang, mencari titik temu bersama, dan mengembalikan hakikat agama sebagai instrumen perdamaian dan kasih sayang. Oleh sebab itu, yang dibutuhkan dalam dialog adalah sikap saling percaya. Artinya, dialog antaragama bukan ajang untuk membandingkan perbedaan atau mengukur benar-tidaknya ajaran agama dan keyakinan peserta dialog, akan tetapi diarahkan untuk mencari persamaan-persamaan yang bisa dijadikan sebagai landasan saling pengertian dan kerja sama.

\footnotetext{
15 Syafaatun al-Mirzanah, When Mystic Master Meet: Paradigma Baru dalam Relasi Umat Kristiani-Muslim (Yogyakarta: SUKA Press, 2007), 6.
} 
Lebih lanjut Swidler menjelaskan sebagai berikut: pertama, tujuan dialog antaragama bukan untuk mencari kebenaran sendiri, tetapi bertujuan untuk memperkaya pengalamaan keberagamaan masingmasing peserta dialog yang kemudian dijadikan sebagai media memampukan diri. Dengan kemampuan tersebut diharapkan bisa mengambil keputusan terbaik dalam kehidupan. Dengan demikian dialog tidak hanya sebatas perjumpaan antarpemeluk agama yang berbeda saja, akan tetapi juga memiliki spirit kemanusiaan bahwa komunitas lain di luar diri kita juga memiliki pengalaman bergama yang bisa diserap dan digunakan untuk memperkaya kehidupan kita. Kedua, dialog merupakan upaya untuk melakukan tukar pengalaman kehidupan keberagamaan di antara peserta dialog. Pengalamaan keagamaan ini penting untuk didialogkan demi mencapai titik temu bersama dalam bingkai kerja sama antarumat beragama. Di sinilah pengalaman beragama atau spiritiualitas masing-masing agama bisa bersifat universal dan tidak parsial. Ketiga, dialog merupakan prakarsa mengembalikan hakikat agama sebagai agama yang damai, saling mengasihi dan saling menghormati. ${ }^{16}$ Di sinilah dalam dialog antaragama terdapat asas dan tujuan bagi kerja sama antarumat beragama untuk mencapai keadilan, kemerdekaan, persatuan, kerukunan, kemakmuran dan perdamaian bersama.

Dalam melihat relasi antara agama, keragaman tidak dapat dihindarkan, keragamaan memiliki arti penting dan berharga bagi semua orang. Keragaman tidak hanya berkaitan dengan persoalan perbedaan, tetapi juga memiliki makna penting untuk setiap mansia. Oleh sebab itu, nilai-nilai agama seharusnya bisa dibagikan dan dikomunikasikan dengan komunitas agama lainnya. Dalam konteks ini, menurut John S. Dune diperlukan sikap passing over dan come back. Artinya, umat beragama harus keluar dari dalam kesadaran agamanya sendiri dan masuk pada kesadaran agama lain. Dalam kalimat lain, seseorang bersikap empati dengan ketulusan memahami realitas agama lain untuk mematangkan pemahaman keagamaannya, kemudian dia harus kembali pada keagamaannya sendiri yang tentunya dengan wawasan serta pencerahan yang baru. ${ }^{17}$

\footnotetext{
${ }^{16}$ Leonard Swidler, "The Study of Religion in an Age of Global Dialogue", dalam Anas Aidjuddin, Pluralisme dan Tantangan Dialog antar Agama (Jakarta: PT Gramedia Pustaka Utama, 2014), 327.

${ }_{17}$ Budhy Munawar Rachman, Islam Pluralis: Wacana Kesetaraan Kaum Beriman (Jakarta: Paramadina, 2001), 98.
} 
Passing over dan come back ini menuntut adanya pengungkapan kesadaran diri sebagai spirit dalam membangun hubungan antaragama. Spirit ini akan mengantarkan seseorang untuk bisa melakukan self critism (kritik pada diri sendiri), sebab dalam pemahamannya sudah tidak lagi berkaitan dengan klaim-klaim eklusvisme agama. Dengan kritik internal ini, seseorang akan lebih terbuka untuk menerima pengalaman keberagamaan orang lain, yang kemudian bisa diambil hikmahnya untuk mematangkan dan mendewasakan pribadinya. Dengan demikian, dalam dialog, jika seseorang hanya berhenti pada passing over saja tidaklah cukup, melainkan ia harus mendorong dirinya sampai pada come back.

Berangkat dari hal ini, mengutip pendapat Amin Abdullah, "setiap orang berpartisipasi di dalam kehidupan Tuhan". Dengan demikian umat beragama bisa mendialogkan persoalan kemanusiaan dengan komunitas lainnya. Cara pandang ketika melihat umat yang lain juga akan berbeda, bukan lagi sebagai musuh yang mengancam, akan tetapi lebih sebagai partner dalam mewujudkan keadilan, kebersamaan, kesetaraan dan kesejahteraan sosial. Pola ini akan menjadikan pemahaman umat beragama bergeser dari pemahaman keagamaan yang absolute claim (kebaikan dan keselamatan dari diri sendiri) menuju model pemahaman yang pluralistik, bersifat intersubjektif, mengedepankan dialogical, comunicable, and on going proces dalam beragama.

Contoh baik yang dapat dihadirkan pada zaman ini adalah dialog antara umat Islam dan Kristen yang menghasilkan $A$ Common Word, sebuah dokumen dialog antar-agama "terbesar" yang ada di antara kedua komunitas agama ini. Dialog yang terjadi pada tahun 2007 tersebut kemudian berkembang menjadi spirit dialog di berbagai penjuru dunia. Dalam dialog tersebut, kedua komunitas sama-sama melihat perlunya pengembangan pemahaman atas cinta kepada Tuhan dan cinta kepada sesama manusia. Dua kecenderungan bangunan relasi antara Muslim dan Kristiani, yaitu persatuan dalam perbedaan dan pertemanan dalam perbedaan, digunakan secara bersama-sama dalam berdialog. Hasilnya adalah sebuah dokumen yang kemudia diberi nama $A$ Common Word Between Us and You, sebuah kata bersama, Kalimat Sawä, yang di dalamnya terdapat sikap terbuka dan tidak menerima nilai dari agama lainnya tanpa sikap kritis. ${ }^{18}$

18 Anas Aijuddin, Pluralisme dan Tantangan Dialog Antar Agama (Jakarta: Gramedia Pustaka Utama, 2014), 330. 
Kalimat Sawā' atau Common Word dipandang merangkum kedua kecenderungan relasi Muslim dan Kristen sekaligus, yaitu adanya kecenderungan: pertama, persatuan dalam perbedaan tercermin dari redaksi tajuknya sendiri, yakni $A$ Common Word Between Us and You. Kata common atau sawā' dalam redaksi tersebut berkonotasi kuat bahwa semua hal besifat sementara, seimbang dan level yang sama. Meski demikian, tujuannya bukan untuk membentuk agama baru, agama sinkretis, melainkan mengakui adanya perbedaan dan mencari titik temu bersama. Sementara itu kecenderungan kedua, yaitu pertemanan dalam perbedaan, tergambar dari penggunaan kitab suci kedua agama, yaitu al-Qur'ān dan Bibel sebagai acuan pokok. Dalam konteks ini, Kalimat Sawa' menerapkan metode yang unik di mana kedua kitab suci tidak diperbandingkan dalam posisi yang saling berhadapan. Pembacaan terhadap teks al-Qur'ān dan Bibel tentang persamaan pada tema kecintaan kepada Tuhan dan kecintaan kepada tetangga ditunjukkan oleh kitab suci kedua agama tersebut secara seimbang. Hal semacam ini, menurut Nicholas Adam, bahwa Kalimat Sawä' diumpamakan sebagai alat pembangkit kekuatan elektromagnetik. Artinya, al-Qur'ān dan Bibel adalah sumber kekuatan magnetik di mana satu dengan yang lain saling didekatkan, sehingga menghasilkan sebuah energi dialog yang luar biasa besarnya. Dengan demikian, dialog tidak sebatas acara seremonial, pertemuan antara dua komunitas yang berbeda, akan tetapi dialog memiliki makna sebagai bagian dari kesadaran kemanusiaan, sekaligus mengandung etika kehidupan. Lebih dari itu, dialog merupakan interaksi antarmanusia yang paling berharga. Pendapat ini bisa menghantarkan umat Islam pada pola keberagamaan yang lebih terbuka dan toleran, lebih menghargai orang lain. ${ }^{19}$

Kesadaran diri dalam dialog inilah yang akan menjadikan umat beragama bisa melakukan factual correction (koreksi faktual) di mana umat berbeda agama dan keyakinan bisa bertemu, bersama dan hidup saling menghormati, bisa saling memberikan klarifikasi atas pandangannya masing-masing. Dengan demikian, umat beragama akan mengalami, memaknai dan menciptakan realitas tersebut bersama dengan umat beragama yang lainnya. Pandangan ini lebih menitikberatkan pada bagaimana value dari masing-masing agama dikelola, dikembangkan untuk mencapai keselamatan bersama. Dalam

${ }^{19}$ Anas Aidjuddin, Pluralisme dan Tantangan Dialog antar Agama (Jakarta: PT Gramedia Pustaka Utama, 2014), 321. 
bahasa lugas, nilai pluralitas dalam masyarakat harus didorong pada ranah common society, membentuk masyarakat bersama, masyarakat yang tidak sektarian, yang mampu membangun konsensus sosial dalam kehidupan kesehariannya. Pandangan pluralisme ini bisa terwujud jika digali dari akar penafsiran yang tidak tekstualis, tidak skriptualis dan tidak jumud, namun sebaliknya teks keagamaan digali makna yang terkandung di dalamnya kemudian dicari relevansinya dalam konteks saat ini.

Menurut M. Amin Abdullah, setiap agama memiliki commonalitas, common patern atau al-masküt 'anh yang tidak terekspresi ke luar. Dalam setiap agama terdapat unsur-unsur kesamaan yang sifatnya absolut, bukan relatif, yaitu sifat humanitarian, keadilan, keprihatinan pada lingkungan hidup, dan menolong orang yang terpinggirkan. ${ }^{20}$ Dengan demikian, kembali mengutip pernyataan Syafaatun al Mirzanah, dialog antarumat beragama seharusnya tidak berkutat pada persoalan di mana Tuhan dalam keimanan dan praktik masing-maisng agama, namun hendaknya sampai pada persoalan bagaimana memahami dan di mana kita dapat menemukan Tuhan dalam keimanan dan praktik agama lain.

Berangkat dari sinilah, dalam dialog, umat beragama bisa belajar banyak hal, seperti: pertama, bisa bersikap terbuka berkaitan dengan persoalan keimanan. Kedua, bisa bersikap lebih demokratis karena dalam dialog, umat beragama akan memandang mitra dialog secara setara. Ketiga, bersedia memahami sesuatu dari sudut pandang mitra dialog, tanpa harus mengikuti keyakinannya sebagai kebenaran. Keempat, belajar memandang sesuatu dalam keyakinan mitra dialog dari sudut pandang mitra dialog, dan tidak terperangkap dalam sudut pandang sendiri. ${ }^{21}$ Maka dialog merupakan sarana bagi seseorang atau komunitas untuk meningkatkan daya kepedulian mereka dan kejujuran dalam kehidupan. Dialog bukanlah sarana untuk mencari perbedaan atau meruncingkan perbedaan, akan tetapi sarana untuk menguatkan sikap empati (respect), kejujuran (trust), dan pershabatan (genuine friendship). Lebih dari itu dengan dialog umat beragama akan mendapatkan bandingan dan pengayaan akan perspektif agama mereka. Dialog bagi umat beragama adalah meda untuk

\footnotetext{
${ }^{20}$ M. Amin Abdullah, Dinamika Islam Kultural: Pemetaan atas Wacana Islam Kontemporer (Bandung: Mizan 2000), 75-79.

${ }^{21}$ Badru D. Kateregegga, Dialog Islam dan Kristen (Semarang: Pustaka Muria, 2007), 16.
} 
memberdayakan dan meningkatkan kualitas keimanannya sendiri secara lebih baik.

\section{Beragama Secara Kritis-Komprehensif}

Dalam rangka studi kritis-komprehensif atas konsep beragama, Amin Abdullah mengajak umat beragama untuk memiliki rasa empati terhadap agama, karena melalui proses empati keagamaan ini, umat beragama akan bisa memahami agama sebagai fenomena universal. Menurut Amin, cara beragamang kritis-komprehensif dapat digambarkan dalam tiga aspek, yaitu firstnes, secondness, dan thirdness. ${ }^{22}$

Aspek pertama adalah firstness, yakni dimensi subjektif yang berkaitan dengan wacana yang menjadi landasan metafisis dalam konteks beragama, seperti religiusitas, spritualitas, dan keadilan objektif. Amin menempatkan metafisika sebagai alat analisis untuk menemukan Common Word antara agama-agama, khususnya Islam dan Kristen. Dalam konteks ini, metafisika berfungsi sebagai alat analisis yang melampui teologi yang pada kenyataannya selalu terjebak pada pencarian justifikasi dogmatik dan klaim kebenaran secara absolut yang pada gilirannya seringkali menjadi salah satu pemicu konflik antarumat beragama. Kedua, metafisika berfungsi untuk mentransendensikan antagonisme teologi dengan jalan mengafirmasi ulang dan meremajakan bentuk teologi lewat ilustrasi bagaimana sebuah bentuk berasal dan apa tujuannya. Artinya, teologi memiliki ragam keterbatasan dalam dirinya, sehingga tidak memungkinkan untuk bisa mempertemukan kutub kebenara masing-masing agama. Hanya melalui metafisikalah dialog antaragama bisa terwujud.

Aspek kedua adalah secondness, yakni dimensi objektif dari wacana agama. Pada titik ini cara beragama adalah dengan mengedepankan sejarah agama sebagai aspek untuk menelusuri dimensi tradisi atau latar belakang di antara agama-agama yang ada dan diharapkan akan menemukan titik temu (Kalimat Sawāa). Hal ini dimaksudkan untuk membangun dialog yang berlandaskan aspek kecintaan terhadap Tuhan sebagai bangunan metafisikanya serta ruang kemanusiaan sebagai aspek eksoterisnya.

Aspek ketiga adalah thirdness, yakni dimensi intersubjektif dari wacana agama. Pada titik ini, Amin menemukan bahwa pemahaman keagamaan telah mengalami perubahan orientasi kajian dari diskursus metafisis-teologis ke diskursus humanis-postmetafisis. Artinya,

22 Abdullah, "Relevansi Studi Agama-Agama", 56. 
beragama harus bisa mengarah pada teologi kritis. Penekanannya adalah bahwa tampilan agama di ruang publik secara kritis paling tidak dikonstruksi oleh dua hal, yaitu munculnya hubungan reflektif atas keyakinan seseorang dalam horizon universalitas agama, dan adanya pendekatan etis yang memunculkan konteks sebagai agama untuk bersepakat atas prinsip-prinsip dasar moralitas. Wacana ini pada dasarnya menjadikan toleransi (tasāmuh̆) sebagai landasan dalam meletakkan sikap menerima, menolak, dan menyangkal yang kemudian dikembangkan sebagai pola sikap epistemik.

Sikap toleransi diperlukan untuk dapat memahami dan menerima agama lain. Menjadi pertanyaan fundamental bagi seorang Muslim apakah ayat-ayat Tuhan (al-Qur'ān) menghendaki kekerasan dan sikap radikal? Ataukah justru sebaliknya bahwa al al-Qur'ān turun untuk menghentikan ekspresi-ekspresi kekerasan, kebanggaan personal dan menleyapkan tidakan serta gerakan saling menindas sesama manusia dan memperkuat aspirasi-aspirasi sosial?

Diakui memang ada pertarungan interpretasi dalam menafsirkan ayat-ayat Al-Qur'ān yang bernuansa eksklusif di satu sisi, dan bernaunsa inklusivisme di lain sisi. Pandangan eksklusif berkembang dan tumbuh dengan kuat. Kelompok pengusung eksklusivisme memiliki pemahaman monolitik bahwa hanya ada satu cara tafsir yang mutlak benar yaitu cara tafsir mereka, sementara penafsiran lain salah bahkan sesat. Kelompok eksklusif cenderung menilai agama lain menggunakan standar penilain yang mereka buat sendiri. Mereka memvonis dan menghakimi bahwa hanya agamanya yang autentik berasal dari Tuhan, sementara agama lain 'mungkin' berasal dari Tuhan kemudian megalami perombakan dan pemalsuan oleh penganutnya sendiri, atau bisa jadi agama lain tersebut adalah hasil konstruksi umat manusia. Kelompok ini mengambil dalil dari alQur'ān, seperti ayat 85 surah Āl 'Imrān:

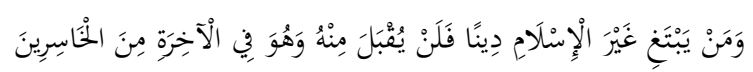

"Barangsiapa mencari agama selain agama Islam, maka sekali-kali tidaklah akan diterima (agama itu) daripadanya, dan dia di akhirat termasuk orang-orang yang rugi."

Begitu pula potongan awal ayat 19 di dalam surah yang sama:

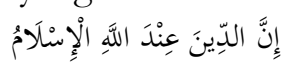

"Sesungguhnya agama (yang diridai) disisi Allah hanyalah Islam."

Bagi kelompok eksklusif, ayat-ayat ini secara normatif memberikan petunjuk bahwa Islam adalah agama yang paling benar dan diridai 
Allah, sementara agama yang lain salah dan sesat. Indikasi berikutnya dari faham ini adalah adanya konsepsi jihäd terhadap kelompokkelompok tertentu di luar Islam, dan pembagian wilayah Dār al-Isläm (wilayah Islam) dan Där al-Harb (wilayah perang, atau wilayah yang harus ditundukkan).

Sementara itu ayat-ayat lain dalam al-Qur'ān memberikan petunjuk bagi kaum Muslimin untuk bersifat terbuka dan inklusif. Ayat 62 surah al-Baqarah menjadi salah satu rujukan kelompok ini, yaitu:

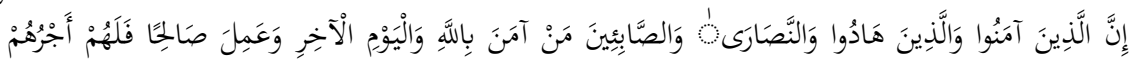

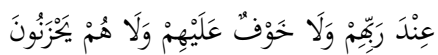

"Sesungguhnya orang-orang mukmin, orang-orang Yahudi, orangorang Nasrani dan orang-orang Shabiin, siapa saja di antara mereka yang benar-benar beriman kepada Allah, hari kemudian dan beramal saleh, mereka akan menerima pahala dari Tuhan mereka, tidak ada kekhawatiran kepada mereka, dan tidak (pula) mereka bersedih hati."

Selanjutnya adalah ayat 48 surah al-Mā'idah:

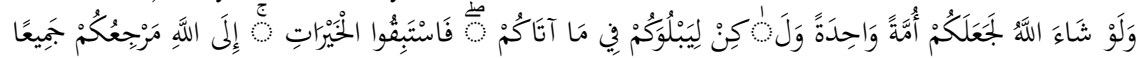

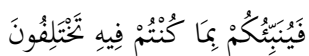

"Sekiranya Allah menghendaki, niscaya kamu dijadikan-Nya satu umat (saja), tetapi Allah hendak menguji kamu terhadap pemberianNya kepadamu, maka berlomba-lombalah berbuat kebajikan. Hanya kepada Allah-lah kembali kamu semuanya, lalu diberitahukan-Nya kepadamu apa yang telah kamu perselisihkan itu."

Beberapa penafsiran yang dapat ditarik dari ayat tersebut adalah:

1. Tiap-tiap umat atau masyarakat memiliki syariat, aturan dan jalanya masing-masing. Setiap umat wajib untuk meyakini syariat atau ajaran agamanya sendiri, karena Allah menguji atas apa yang telah diberikan-Nya itu.

2. Setiap umat atau kelompok masyarakat wajib berlomba-lomba dalam kebaikan dan kebijakan, mengisi kehidupan ini dengan prestasi dan apresiasi.

3. Kelak di hari akhir nanti Allah akan memberikan putusan terhadap apa yang diperselisihkan oleh manusia di bumi ini, maka tidak ada hak bagi orang lain untuk menghakimi dan memberikan vonis. ${ }^{23}$

${ }^{23}$ Abu Bakar MS, "Argumen al-Qur'an tentang Eksklusivisme, Inklusivisme, dan Pluralisme”, Toleransi: Media Komunikasi Umat Beragama, Vol. 8, No. 1 (2016), 51. 
Jika al-Qur'ān mengajarkan sikap inklusif bagi masyarakat Muslim, maka umat Islamlah, sebagai penafsir, yang memainkan peranan penting untuk membuat al-Qur'ān "berbicara" dalam konteks kebutuhan modern serta menjawab tantangan dinamika hubungan antarmasyarakat manusia pada konteks kekinian. Bukankah Nabi Muhammad dan Islam adalah rabmah li al-älamin? Kesalahan pembacaan terhadap teks al-Qur'ān akan menggiring pembacanya kepada klaim-klaim eksklusif dan pemahaman literal dan mencap orang di luar golongannya sebagai yang salah dan sesat. Konsekuensinya, kelompok-kelompok yang dianggap sesat ini harus bertobat dan kembali ke jalan yang benar. Jika mereka enggan maka mereka harus diperangi. Kelompok Muslim eksklusif menggunakan ayat 39 surah al-Anfāl sebagai argumentasi:

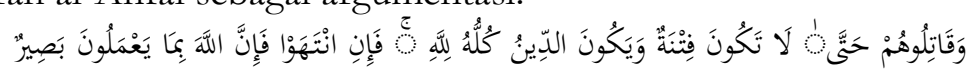

"Dan perangilah mereka, supaya jangan ada fitnah dan supaya agama itu semata-mata untuk Allah. Jika mereka berhenti (dari kekafiran), maka sesungguhnya Allah Maha Melihat apa yang mereka kerjakan."

Hal senada ditemukan juga dalam ayat 29 surah al-Tawbah:

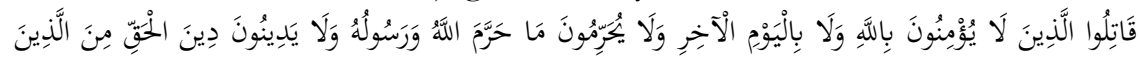

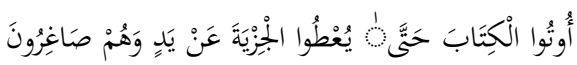

"Perangilah orang-orang yang tidak beriman kepada Allah dan tidak (pula) kepada hari kemudian, dan mereka tidak mengharamkan apa yang diharamkan oleh Allah dan Rasul-Nya dan tidak beragama dengan agama yang benar (agama Allah), (yaitu orang-orang) yang diberikan Al-Kitab kepada mereka, sampai mereka membayar jizyah dengan patuh sedang mereka dalam keadaan tunduk."

Pembacaan terhadap ayat-ayat seperti di atas seharusnya lebih terbuka, toleran dan inklusif dengan memperhatikan dengan seksama sisi moralitas al-Qur'ān dan historisnya. Sayangnya, pembacaan yang terbuka dan toleran itu sering dicap sebagai penyimpangan dari mainstream ilmu tafsir dan menyalahi kaidah-kaidah usüliyah. Menyikapi hal ini, sebagaimana dikutip oleh Nurcholish Madjid, Ibn Taymīyah memberikan pemahaman tentang pengertian Islam yang ada dalam berbagai ayat al-Qur'ān:

Orang berselisih tentang umat terdahulu, seperti umat Nabi Musa dan umat Nabi Isa, apakah mereka itu orang-orang Muslim atau tidak? Ini adalah perselisihan kebahasaan. Sebab "Islam khusus" yang dengan itu Allah mengutus Nabi Muhammad dan yang 
meliputi syariat al-Qur'ān tidak ada yang berada di atasnya kecuali umat Nabi Muhammad saw dan "Islam" pada saat sekarang secara keseluruhan berlaku hanya untuk ini. Sedangkan "Islam umum" yang berlaku untuk setiap syariat yang dengan itu Allah bangkitkan seorang nabi, maka ia berlaku untuk islamnya setiap umat yang mengikuti salah seorang nabi. Pangkal Islam itu secara mutlak ialah persaksian bahwa tiada tuhan selain Allah, dan dengan persaksian itulah semua rasul dibangkitkan, sebagaimana difirmankan Allah Ta'ala: "Sungguh telah Kami (Allah) bangkitkan untuk setiap umat seorang rasul (mereka menyeru). Sembahlah olehmu semua Allah (Tuhan Yang Maha Esa) saja, dan jauhilah (lawanlah) kekuatan jahat (thaghut), kekuatan tiranik)". (Q.S. al-Nahl [16]: 36); dan firman Allah: "Tidaklah Kami (Allah) mengutus seorang rasul pun sebelum engkau (Muhammad) melainkan Kami wahyukan kepadanya bahwa tiada tuhan selain Aku, karena itu sembahlah olehmu semua (wahai umat manusia) akan Daku saja." (Q.S. alAnbiyā' [21]: 25."24

Membaca atau menafsirkan kata Islam, paling tidak dalam tiga ayat di atas dengan pengertian Islam 'Āmm. Karena itu, Islam dalam pengertian ini tidak hanya bagi umat Nabi Muhammad saja, melainkan secara universal, termasuk umat-umat terdahulu. Berangkat dari pengertian ini kemudian kata Islam diterjemahkan sebagai sikap pasrah kepada Tuhan, sebagaimana sikap-sikap yang telah diteledankan oleh para nabi sebelum Nabi Muhammad.

\section{Catatan Akhir}

Dialog agama pada posisi "menerima" merupakan kondisi awal bagi adanya toleransi serta adanya pengakuan terhadap pluralitas. Sikap yang subjektif harus bergeser ke inter-subjektif dalam ranah sosial. Dari perbedaan yang ada, semua kalangan harus bisa menerima, karena merupakan syarat untuk tercapainya hidup damai. Sikap saling menghormati merupakan sikap yang memungkinkan untuk semua pihak agar bisa saling menerima dengan menghilangkan adanya kecurigaan yang berlebihan terhadap kelompok agama lain. Sikap toleran merupakan kehendak untuk bersedia mendengarkan dan terbuka terhadap pihak lain, dan poin ini menjadi hard core dalam membangun kehidupan keagamaan yang kritis, harmonis, sehat, dan nirkekerasan.

24 Nurcholish Madjid, Islam Doktrin dan Peradaban (Jakarta: Yayasan Wakaf Paramadina, 2000), 466. 


\section{Daftar Rujukan}

Abdullah, M. Amin. "Relevansi Studi Agama-agama dalam Milenium Ketiga: Upaya Memecahkan Persoalan Keagamaan Kontemporer," Jurnal Ulumul al-Qur'ān, No. 5, Vol. VII.

-----. "Studi Islam Ditinjau dari Sudut Pandang Filsafat: Pendekatan Filsafat Keilmuan", dalam Amin Abdullah, dkk., Restrukturisasi Metodologi Islamic Studies Madhab Yogyakarta. Yogyakarta: SUKA Press, 2007.

-----. Dinamika Islam Kultural: Pemetaan atas Wacana Islam Kontemporer. Bandung: Mizan 2000.

Aidjuddin, Anas. Pluralisme dan Tantangan Dialog antar Agama. Jakarta: PT Gramedia Pustaka Utama, 2014.

al-Mirzanah, Syafa'atun. When Mystic Master Meet: Towards a New Matrix for Christian-Muslim Dialogue. New York: Blue Domes Press, 2011.

Boy, Pradana. Fikih Jalan Tengah: Dialetika Hukum Islam dan Masalahmasalah Masyarakat Modern. Jakarta: Penerbit Hamdalah, 2008.

Fata, Ahmad Khoirul dan Fauzan. 'Kritik 'INSIST' terhadap Gagasan Pluralisme Agama", Kalam, Vol. 11, No. 1, 2017.

-----. "Liberalisme Islam di Indonesia: Gagasan dan Tanggapan tentang Pluralisme Agama". Tesis--IAIN Sunan Ampel Surabaya, 2006.

-----. "Menguak Islam Eksklusif yang Toleran", Islamica: Jurnal Studi Keislaman, Vol. 6, No. 1, 2011.

Harb, Ali. Nalar Kritis Islam Kontemporer, terj. Umar Bukhory dan Ghazy Mubarak. Yogyakarta: IRCiSoD, 2012.

Helminita, Karlina. Agama dan Hak Asasi Manusia: Landasan Filosofis Konsep Hak. Asasi Manusia. Jakarta: CSRC UIN Syarif Hidayatullah, 2009.

Kateregegga, Badru D. Dialog Islam dan Kristen. Semarang: Pustaka Muria, 2007.

Kimbal, Charles. When Religion Becomes Lethal. San Fransisco: Jossey Bass 2011.

Lockhead, David. "The Dialogical Imperative", dalam Anas Aijuddin, Plurallisme dan Tantangan Dialog antar Agama. Jakarta: Gramedia Pustaka Utama, 2014.

Madjid, Nurcholish. Islam Doktrin dan Peradaban. Jakarta: Yayasan Wakaf Paramadina, 2000.

Maḥallī (al), Jalāl al-Dīn Muhammad. Jalā' al-'Aynayn 'alā Tafsìr alJalālayn. Kairo: Dār al-Salām, 1993. 
Mibtadin. Nalar Kritis dalam Beragama. Jakarta: Gramedia Pustaka, 2014.

MS, Abu Bakar. "Argumen al-Qur'an tentang Eksklusivisme, Inklusivisme, dan Pluralisme", Toleransi: Media Komunikasi Umat Beragama, Vol. 8, No. 1, 2016.

Rachman, Budhy Munawar. Islam Pluralis: Wacana Kesetaraan Kaum Beriman. Jakarta: Paramadina, 2001.

Swidler, Leonard. "The Study of Religion in an Age of Global Dialogue", dalam Anas Aidjuddin, Pluralisme dan Tantangan Dialog antar Agama. Jakarta: PT Gramedia Pustaka Utama, 2014.

Vitria, Fita. "Konflik Peradaban Samuel P. Huntington: Kebangkitan Islam yang Dirisaukan”, Humanika, Vol. 9, No. 1, 2009. 